\title{
Deuterium Solvent Isotope Effect and Proton Inventory Studies of Factor Xa-catalyzed Reactions ${ }^{\dagger}$
}

\author{
Daoning Zhang§ and Ildiko M. Kovach * \\ The Catholic University of America, Chemistry Department, Washington DC 20064
}

\section{Abstract}

Kinetic solvent isotope effects (KSIE) for the Factor Xa (FXa)-catalyzed activation of prothrombin in the presence and absence of Factor $\mathrm{Va}(\mathrm{FVa})$ and $5.0 \times 10^{-5} \mathrm{M}$ phospholipid vesicles, are slightly inverse, $0.82-0.93$, when substrate concentrations are at $0.2 \mathrm{~K}_{\mathrm{m}}$. This is consistent with ratedetermining association of the enzyme-prothrombin assembly, rather than rate-limiting chemical transformation. FVa is known to effect a major conformational change to expose the first scissile bond in prothrombin, which is the likely event triggering a major solvent rearrangement. At prothrombin concentrations $>5 \mathrm{~K}_{\mathrm{m}}$ the KSIE is $1.6 \pm 0.3$, when FXa is in $1: 1$ ratio with FVa, but becomes increasingly inverse, $0.30 \pm 0.05$ and $0.19 \pm 0.04$, when FXa : FVa 1:4, with increasing FXa concentration and substrate concentration. The rate-determining step changes with the conditions, but the chemical step is not limiting under any circumstance. This corroborates the proposed predominance of the meizothrombin pathway when FXa is well saturated with the prothrombin complex. In contrast, the FXa-catalyzed hydrolysis of N- $\alpha$-Z-D-Arg-Gly-ArgpNA.2HCl (S-2765) and H-D-Ile-L-Pro-L-Arg-pNA.HCl (S-2288) is most consistent with twoproton bridges forming at the transition state between $\mathrm{Ser}^{195} \mathrm{O} \gamma \mathrm{H}$ and $\mathrm{His}^{57} \mathrm{~N} \varepsilon 2$ and $\mathrm{His}^{57} \mathrm{~N} \delta 1$ and Asp ${ }^{102}$ COO $\beta$ - at the active site, with transition state fractionation factors of $\phi_{1}=\phi_{2}=0.57 \pm 0.07$ and $\phi_{S}=0.78 \pm 0.16$ for solvent rearrangement for S-2765, and $\phi_{1}=\phi_{2}=0.674 \pm 0.001$ for S-2288 under enzyme saturation with substrate at $\mathrm{pH} 8.40$ and $25.0 \pm 0.1^{\circ} \mathrm{C}$. The rate-determining step(s) in these reactions is most likely the cleavage of the $\mathrm{C}-\mathrm{N}$ bond and departure of the leaving group.

Factor Xa (FXa) is one of the best characterized of the serine proteases in the cardiovascular system.(1-6) It catalyzes the efficient activation of a large precursor protein, prothrombin, to form $\alpha$-thrombin. $(1 ; 7 ; 8)$ Although several proteolytic enzymes can bring about this reaction, it is FXa that performs this key function under physiological conditions. On the basis of extensive investigations, the prothrombin complex is known to consist of phospholipid surface, prothrombin, $\mathrm{Ca}^{2+}$ and factor $\mathrm{Va}(\mathrm{FVa}) .(8-12)$ This construct facilitates the activation of prothrombin by $\sim 3 \times 10^{5}$-fold over catalysis by FXa alone. $(13 ; 14)$ The activation of human prothrombin involves the hydrolysis of two peptide bonds, $\mathrm{Arg}^{322}-\mathrm{Ile}^{323}$ followed by $\mathrm{Arg}^{273}$ $\mathrm{Thr}^{274}$. In contrast, when FXa acts alone, bond cleavage occurs in the opposite order. Different intermediates are formed in the two pathways that have also been studied independently.( 9 ;

14) More in-depth kinetic studies lately revealed that an appreciable fraction of prothrombin is channeled directly to thrombin product without releasing intermediate products.(14)

\footnotetext{
${ }^{\dagger}$ This work was supported in part by the US National Institutes of Health, Grant No 1 R15 HL067754-01.

*Corresponding author. Telephone: (202) 319-6550. FAX: (202) 319-5381. Email: kovach@ cua.edu.

$\S$ Current Address: Center for Biomolecular Structure \& Organization, Department of Chemistry \& Biochemistry, University of Maryland, College Park, MD 20742-3360
}

Supporting Information Available. Two figures and fourteen tables of kinetic rate constants and their ratios for KSIEs and proton inventories. kovach@cua.edu 
FXa activation of prothrombin without FVa is inadequate for survival. FVa itself is processed from FV by cleavage by (human) thrombin at $\mathrm{Arg}^{709}$ into a heavy and a light chain.(10) Both chains are required for the interaction with $\mathrm{FXa}$, but only the heavy chain binds prothrombin without $\mathrm{Ca}^{2+}$.(11) The binding sites for FXa and prothrombin have been located in the middle section(11) and the COOH terminus(12) of the heavy chain of FVa, respectively.(15) In fact, an exosite of FXa, which is exposed upon interaction with FVa for prothrombin tethering, seems to contain amino acids near the active site of the enzyme. This can serve to provide optimal docking of the scissile bonds of prothrombin. The crystal structures of meizothrombin desF1 and prothrombin- 2 show the two prothrombin cleavage sites $36 \AA$ apart.(16) For prothrombin to be cleaved at $\mathrm{Arg}^{322}$, a rotation around the $\mathrm{Gly}^{319}$ and $\mathrm{Gly}^{324}$ hinge points has to occur. The rate of cleavage at the second site is not affected much by the presence of FVa. (11)

Like other proteases,(17) FXa uses a general-base catalytic apparatus (the catalytic triad), in addition to an oxyanion hole and an elaborate binding site for prothrombin. Deuterium kinetic solvent isotope effects (KSIEs)(18-22) have been used to establish the occurrence of proton bridges at the rate-determining transitions state(s) (TSs) in biological general acid basecatalyzed reactions.(23) An extension of the KSIE studies to partial solvent isotope effects or proton inventories has provided additional information on the number and nature of proton bridges at the rate-determining TSs. Proton inventories are measured in mixtures of buffered water and heavy water.(18-22;24-29)

A close relative of FXa is $\alpha$-thrombin, the product of FXa catalysis and the central enzyme in the blood cascade. We have in the recent past presented conclusions from the analysis of proton inventory data obtained on the human $\alpha$-thrombin-catalyzed hydrolysis of natural substrates and oligopeptide mimics of them.(30;31) In thrombin-catalyzed reactions, as in the pancreatic proteases, multi-proton catalysis pertains to proton bridges between $\mathrm{N} \varepsilon 2$ of $\mathrm{His}^{57}$ and the $\mathrm{O} \gamma \mathrm{H}$ of $\mathrm{Ser}^{195}$ and $\mathrm{N} \delta 1$ of $\mathrm{His}^{57}$ and COO $\beta$ - of $\mathrm{Asp}^{102}$ at the active site. $(23 ; 31)$ We carried out proton inventory experiments for the human $\alpha$-thrombin-catalyzed activation of fibrinogen into fibrinopeptide $\mathrm{A}$, the formation of fibrin colloid and the human $\alpha$-thrombin-catalyzed activation of protein $\mathrm{C}$ (PC) to activated protein $\mathrm{C}$ (APC).(30) The proton inventories for fibrinogen activation are bowl shaped and are most consistent with two proton bridges forming at the TS of the chemical process at all substrate concentrations. In contrast, the activation of PC gives KSIEs slightly inverse at substrate concentrations below $\mathrm{K}_{\mathrm{m}}$, indicating the dominance of physical rather than chemical steps limiting the rate under these conditions.

The effect of $\mathrm{P}$ site interactions with $\mathrm{S}$ binding sites on protease enzymes has been established by a variety of studies including proton inventories. The last of these was our study of thrombincatalyzed reactions of oligopeptide substrates.(31) When the requisite number and kind of P$\mathrm{S}$ site interactions are present, the H-bonding distance between proton acceptors and donors of the catalytic triad contracts at the rate-determining TS. We have also shown that the hallmark of the effect of $\mathrm{P}^{\prime}$ residues in leaving group departure is a conformational change associated with a major rearrangement of solvating water. In thrombin-catalyzed reactions, a net increase occurs in the isotopic fractionation factors for hydrogen bonds at solvation sites in the ratedetermining step. This effect is elicited by interactions at the leaving groups' binding site or substrate specificity site, which observation is well supported by other studies of $\mathrm{P}^{\prime}$ site interactions in catalysis(32-34) by and inhibition(35) of proteases. The proton inventory technique has been particularly revealing about the importance of solvent reorganization in substrate binding and leaving group release in thrombin-catalyzed reactions.

The premise of this endeavor has been that association and rearrangement of the FXaprothrombin assembly is likely to limit the rate at the aqueous-lipid interface, as the very role of activation on heterogeneous surfaces is the facilitation of chemical transformation by 
juxtaposing and binding reactant partners. The process is associated with solvent restructuring and, thus, the physiological reaction catalyzed by FXa is likely to show a strong contribution from solvent rearrangement. Indeed, the activation of prothrombin by FXa gave inverse KSIEs that approached $0.2-0.3$ in the presence of FXa : FVa in $1: 4$ ratio and $50 \mu \mathrm{M}$ phospholipid vesicles (LUV), as the substrate concentrations were raised above $\mathrm{K}_{\mathrm{m}}$, indicating the dominance of physical rather than chemical steps limiting the rate at the aqueous-lipid interface. In the presence of FXa : FVa $=1: 1$ and at enzyme saturation with substrate, however, the KSIEs became small normal, i.e. greater than 1.0. To obtain an unmasked picture of the ratedetermining events in peptide bond hydrolysis catalyzed by FXa, we also studied proven mimics of the natural substrates with the proton inventory technique. FXa-catalyzed reactions of chromogenic substrates behaved similarly to the thrombin-catalyzed reactions of oligopeptide p-nitroanilides or 4-methyl umbelliferones, i.e. showed two-proton bridges at the rate-determining TS. However, N- $\alpha$-Z-D-Arg-Gly-Arg-pNA-2HCl, a very efficient substrate of FXa, hydrolyzed with a contribution from solvent rearrangement at the rate-determining TS while saturated the enzyme. Solvent restructuring is likely to accompany leaving group departure, which then is part of the rate-determining process.

Once more, the results of KSIE and proton inventory studies bring to light the critical importance of the participation of proton bridges and water structure in catalysis of another key serine protease, FXa.

\section{Experimental Procedures}

\section{Materials}

Anhydrous dimethyl sulfoxide (DMSO), heavy water with $99.9 \%$ deuterium content, and anhydrous methanol were purchased from Aldrich Chemical Co.. All buffer salts were reagent grade and were purchased from Aldrich, Fisher, or Sigma Chemical Co.. Solid bovine FXa, MM $45300 \mathrm{~d}, 0.8 \mathrm{U} / \mathrm{mg}$ in powder and Soybean Trypsin inhibitor (STI), $20 \mu \mathrm{g} / \mathrm{mL}$ were purchased from Sigma Chemical Co.. N- $\alpha$-Z-D-Arg-Gly-Arg-4-nitroanilide (pNA)·2HCl (S-2765), 99\% (TLC), H-D-Ile-L-Pro-L-Arg-pNA.HCl (S-2288), 99\% (TLC), and H-D-PhePip-Arg-pNA (S-2238), 99\% (TLC), were purchased from Diapharma Group Inc.. Human FXa, MM 46,000 d, $7.7 \mathrm{mg} / \mathrm{mL}$ in $50 \%$ glycerol/ $\mathrm{H}_{2} \mathrm{O}$, Factor Va, MM 168,000 d, $2190 \mathrm{U} / \mathrm{mg}$ in $50 \%$ glycerol $/ \mathrm{H}_{2} \mathrm{O}$ and $2 \mathrm{mM} \mathrm{CaCl}_{2}$, and prothrombin were purchased from Haematologic Technologies Inc.. Human $\alpha$-thrombin, MM 36,500 d, $3010 \mathrm{NIH} \mathrm{U/mg} \mathrm{in} \mathrm{pH} \mathrm{6.5,} 0.05 \mathrm{M}$ sodium citrate buffer, $0.2 \mathrm{M} \mathrm{NaCl}$, and $0.1 \%$ PEG-8000 was purchased from Enzyme Research Laboratories. The $\mathrm{Na}^{+}$salt of L-phosphatidylserine (PS) from brain and a chloroform solution of L-phosphatidylcholine (PCh) from eggs were purchased from Avanti Polar Lipids Inc..

\section{Instruments and Solutions}

Spectroscopic measurements and the preparation of solutions were as described earlier.(31) Buffers were prepared by weight from Tris-base and Tris- $\mathrm{HCl}$ in the range $\mathrm{pH} 7.1-9.1$ in freshly distilled deionized water or heavy water to contain $0.020 \mathrm{M}$ Tris, $0.15-0.30 \mathrm{M} \mathrm{NaCl}$, $0.1 \%$ PEG-4000, and $5 \times 10^{-3} \mathrm{M} \mathrm{CaCl}_{2}$.

\section{Active-Site Concentrations}

The same stock solution was used for all experiments on the same day with intermittent checking of activity with S-2765. Factor Xa concentrations were calculated from similar determinations using S-2765 as substrate and $\mathrm{k}_{\text {cat }}=240 \mathrm{~s}^{-1}$ at $25^{\circ} \mathrm{C}$ (Diapharma catalog). There was no background hydrolysis of the substrates in the absence of enzyme and the slopes were proportional to FXa concentration within $90 \%$ of the values calculated from weights, as indicated by the provider. 


\section{Prothrombin Activation Catalyzed by Human FXa}

Phospholipid vesicles (LUV) were prepared according to well-tested methods(36;37) from 50 $\mu \mathrm{L}$ of $25 \mathrm{mg} / \mathrm{mL}$ PCh and $50 \mu \mathrm{L}$ of $10 \mathrm{mg} / \mathrm{mL}$ PS, mixed, and dried under He gas. The dried lipids, $1.75 \mathrm{mg}$, were then dissolved in $4 \mathrm{~mL} \mathrm{pH} 7.50$ buffer, $0.15 \mathrm{M} \mathrm{NaCl},\left(\mathrm{Ca}^{2+}\right.$ free) to reach a final concentration of $560 \mu \mathrm{M}$. This stock solution was stored frozen and diluted to $56 \mu \mathrm{M}$ LUV, followed by extrusion before use.

For pseudo-first-order kinetic studies, a $5.0 \mu \mathrm{M}$ prothrombin solution was prepared from a stock solution $(25 \mu \mathrm{M})$ by dilution using $\mathrm{pH} 7.50$ buffer containing $5 \times 10^{-3} \mathrm{M} \mathrm{CaCl}_{2}$. For prothrombin activation in the presence of LUV, $355 \mu \mathrm{L}$ of $56 \mu \mathrm{M} \mathrm{LUV}$ was added to a $5 \mu \mathrm{L}$ of solution of $25 \mathrm{nM} \mathrm{FXa}$ and $100 \mathrm{nM} \mathrm{FVa}$ to attain a final concentration of $0.33 \mathrm{nM}$ of FXa. The mixture was incubated at $25.0 \pm 0.1^{\circ} \mathrm{C}$ for $15 \mathrm{~min}$ and $15 \mu \mathrm{L}$ of $5.0 \mu \mathrm{M}$ prothrombin, to reach $0.20 \mu \mathrm{M}$ in the prothrombin complex $(360 \mu \mathrm{L})$, initiated the reaction. Reactions were also carried out with higher FXa concentrations and at different prothrombin concentrations, but in the absence of FVa and LUV.

For initial rate measurements, $41.7 \mathrm{nM} \mathrm{FXa} \mathrm{(FXa} \mathrm{:} \mathrm{FVa}=1: 4)$, in $\mathrm{pH} 7.50$ buffer, $0.15 \mathrm{M}$ $\mathrm{NaCl}$ and $5 \times 10^{-3} \mathrm{M} \mathrm{CaCl}_{2}$ was prepared with $56 \mu \mathrm{M} \mathrm{LUV}$, aliquoted at $10 \mu \mathrm{L}$ volume, and kept at $-20^{\circ} \mathrm{C}$. Prior to the reaction, $10 \mu \mathrm{L}$ FXa solution was mixed with $110 \mu \mathrm{L}$ of $56 \mu \mathrm{M}$ LUV and incubated at $25.0 \pm 0.1^{\circ} \mathrm{C}$ for $15 \mathrm{~min}$. The reaction was initiated by adding $5 \mu \mathrm{L}$ of $100 \mu \mathrm{M}$ prothrombin solution to obtain $4.0 \mu \mathrm{M}$ prothrombin and $3.3 \mathrm{nM} \mathrm{FXa}$ in the prothrombinase complex solution. Reactions were also carried out at different FVa concentrations and at different prothrombin concentrations at $50 \mu \mathrm{M} \mathrm{LUV}$. In all cases, an aliquot of $20 \mu \mathrm{L}$ was drawn at different time intervals to test the amidolytic activity of thrombin produced. The sample was added to $715 \mu \mathrm{L}$ of $\mathrm{pH} 7.50$ buffer and $0.15 \mathrm{M} \mathrm{NaCl}$ and preincubated in a cell at $25.0 \pm 0.1^{\circ} \mathrm{C}$ for $10 \mathrm{~min}$. Fifteen microliters of $3.2 \times 10^{-3} \mathrm{M} \mathrm{S}-2238$ in $\mathrm{pH} 7.5$ buffer containing $900 \mathrm{nM}$ Soybean trypsin inhibitor and $0.15 \mathrm{M} \mathrm{NaCl}$ was added to the solution to start the hydrolysis and pNA release was monitored for one min at $405 \mathrm{~nm}$. The thrombin concentration was calculated from the average of slopes of three to five parallel runs and the $\mathrm{k}_{\mathrm{cat}}$ value for S-2238.(31) Repeats from several fresh LUV preparations gave values within $10 \%$. Prothrombin conversion to thrombin occurred near $90 \%$.

\section{FXa-catalyzed Hydrolysis of Chromogenic Substrates}

The FXa-catalyzed hydrolysis at the $\mathrm{pH}$ plateau, in buffers at $\mathrm{pH} 8.40$ and equivalent $\mathrm{pL}(\mathrm{L}=$ $\mathrm{H}$ or D), $0.30 \mathrm{M} \mathrm{NaCl}, 5 \times 10^{-3} \mathrm{M} \mathrm{CaCl}_{2}, 0.1 \%$ PEG4000 and $25.0 \pm 0.1{ }^{\circ} \mathrm{C}$, of S-2288 and S-2765, were monitored at $405 \mathrm{~nm}, \varepsilon=9,420 \pm 101 \mathrm{OD} \mathrm{M}^{-1}$, or $445 \mathrm{~nm}, \varepsilon=1,245 \pm 16$ OD $\mathrm{M}^{-1}$, for the release of p-NA. In all measurements, the enzyme solution was added from the same aqueous stock solution in $0.5-2 \%$, of the total volume of $1.0 \mathrm{~mL}$, to the isotopic buffer in a cuvette. The mixture was prethermostated for $10-15 \mathrm{~min}$ at the working temperature and the reaction was initiated by the injection of $20 \mu \mathrm{L}$ substrate solution in DMSO. Initial rates of substrate hydrolysis were calculated from 100-1000 absorbance readings at $405 \mathrm{~nm}$ in one min and first-order or full progress curves contained 1,000 points. Good pseudo-first-order behavior was observed at $>95 \%$ completion of the reaction $\left(\mathrm{k}_{\mathrm{cat}} / \mathrm{K}_{\mathrm{m}}\right)$.

The reactions were carried out in 0.5 or $1.0 \mathrm{~mL}$ volumes containing $1.9 \times 10^{-9} \mathrm{M}$ Bovine FXa, S-2288 concentrations between $1.30 \times 10^{-4} \mathrm{M}$ and $3.46 \times 10^{-3} \mathrm{M}\left(\mathrm{K}_{\mathrm{m}}=1.7 \times 10^{-3} \mathrm{M}\right)$ for determining Michaelis-Menten parameters and at $2.88 \times 10^{-3} \mathrm{M}$ for proton inventory studies using initial velocity measurements. The human FXa-catalyzed hydrolysis of S-2765 was studied at $14.5 \times 10^{-9} \mathrm{M}$ FXa and $1.0 \times 10^{-3} \mathrm{M}$ substrate $\left(\mathrm{K}_{\mathrm{m}}=2.6 \times 10^{-4} \mathrm{M}\right)$ in full progress curves, and at $7.3 \times 10^{-9} \mathrm{M} \mathrm{FXa}$ and $2.0 \times 10^{-5} \mathrm{M}$ substrate for pseudo-first-order kinetics. 


\section{Analysis of Kinetic and Proton Inventory Data}

The integrated Michaelis-Menten equation; (38)

$$
\left((\mathrm{A}-\mathrm{Ao}) / \varepsilon \mathrm{k}_{\text {cat }}[\mathrm{E}\}+\mathrm{K}_{\mathrm{m}} / \mathrm{k}_{\mathrm{cat}}(\ln (\mathrm{Ainf}-\mathrm{Ao}) /(\mathrm{Ainf}-\mathrm{A}))=\mathrm{t}\right.
$$

where A, Ao and Ainf are the absorbance values at time t, 0 and infinity, respectively; $\varepsilon$ is the molar absorbtivity, [E] is the enzyme cocntration, and $\mathrm{k}_{\text {cat }}$ and $\mathrm{K}_{\mathrm{m}}$ are the Michaelis-Menten parameters, was fitted to two sets of 1,000 data points from full progress curves for the FXacatalyzed hydrolysis of S-2765. The calculated $\mathrm{k}_{\mathrm{cat}}$ values for the reaction in each of nine isotopic buffers were used for constructing the proton inventory curve. The Michaeli-Menten parameters calculated were in good agrrement with intial estimates from the first ten-fifty data points and with published values under similar conditions. All data reductions using predefined and custom-defined equations were performed using the GraFit 3.0 and Grafit 5.0 software.

\section{Results}

\section{Activation of Prothrombin}

FXa-catalyzed prothrombin activation occurs on membrane surfaces in vivo. The success of the reaction and the extent of prothrombin conversion to thrombin or meizothrombin in vitro greatly depend on the nature and concentrations of LUV and the auxiliary protein, FVa.(7; $36 ; 37 ; 40$ ) Whereas the yield of prothrombin conversion to thrombin appears to increase with the concentration of LUV (composed of PS and PCh as described in the Experimental), at least up to $2 \times 10^{-3} \mathrm{M}$ PS/PC, the rate of the reaction is maximal around $5 \times 10^{-5} \mathrm{M}$.(36;37) We measured KSIEs predominantly under these conditions and at FXa : FVa $=1: 4$. This FXa : FVa ratio was reported to be optimal and the $\mathrm{K}_{\mathrm{m}}$ value under these conditions is $\sim 10^{-6} \mathrm{M}$. $(37 ; 40)$ Forty to sixty percent of prothrombin has been shown to convert to thrombin via meizothrombin under these conditions. $(36 ; 37)$ The time-dependent production of thrombin was monitored by the amidolytic assay.

Pseudo-first-order kinetics was observed at prothrombin concentrations $<2 \times 10^{-7} \mathrm{M}((\sim 0.2$ $\left.\mathrm{K}_{\mathrm{m}},(37 ; 40)\right)$ at $\mathrm{FXa}: \mathrm{FVa}=1: 4$, shown in Figure 1 . The conditions and the $\mathrm{k}_{\mathrm{cat}} / \mathrm{K}_{\mathrm{m}}$ value are in the first column of Table 1A. Similarly, pseudo-first-order rate constants were measured in the absence of FVa (Table 1A, second column) and in the absence of LUV (Table 1A, third and fourth column). The $\mathrm{K}_{\mathrm{m}}$ value is apparently above the testable concentration range for prothrombin in the absence of LUV. In fact, the rate constant decreases with increasing concentrations of FXa and substrate, possibly due to aggregation.

Initial rates, at $<10 \%$ conversion, were measured at $\sim 4-8 \times 10^{-6} \mathrm{M}\left(\sim 4-8 \mathrm{~K}_{\mathrm{m}}\right)$ in the presence of LUV and FXa : FVa = 1:4, and the slope of the lines, as in the example shown in Figure 2 , gave the initial velocities. Table $1 \mathrm{~B}$ shows $\mathrm{k}_{\mathrm{cat}}$ values calculated from the average of threefour repeats of velocity measurements and the KSIE under a variety of conditions. The KSIEs on $\mathrm{k}_{\text {cat }}$ became increasingly inverse, $0.30 \pm 0.05$ and $0.19 \pm 0.04$ (columns two and one), as the prothrombin concentration was increased to $4.0 \times 10^{-6} \mathrm{M}\left(\sim 4 \mathrm{~K}_{\mathrm{m}}\right)$ and $6.8 \times 10^{-6} \mathrm{M}$ $\left(\sim 6.8 \mathrm{~K}_{\mathrm{m}}\right)$, respectively. On the other hand, initial rate studies gave a KSIE of $1.56 \pm 0.31$, when the FXa:FVa ratio was 1:1 and approaching 2.0, but with poor precision, when the LUV concentration was raised to $2 \times 10^{-3} \mathrm{M}$, and the FXa:FVa ratio was 1:1 (not shown). In the absence of FVa (fourth column in Table $1 \mathrm{~A}$ ), the $\mathrm{k}_{\text {cat }}$ values drop precipitously and the KSIE is still inverse.

\section{FXa-catalyzed Hydrolysis of Chromogenic Substrates}

KSIEs for the bovine FXa-catalyzed hydrolysis of S-2288 were measured for $\mathrm{V}_{\max }$ and $\mathrm{V}_{\text {max }} / \mathrm{K}_{\mathrm{m}}$ to be $2.39 \pm 0.53$ and $1.76 \pm 0.19$, respectively, at $1.9 \times 10^{-9} \mathrm{M}$ enzyme concentration, 
at the $\mathrm{pH}$ of the maximal rate, 8.40 and equivalent $\mathrm{pL}, 0.020 \mathrm{M}$ Tris, $0.30 \mathrm{M} \mathrm{NaCl}$ and $5 \times$ $10^{-3} \mathrm{M} \mathrm{CaCl}_{2}$. The Michaelis-Menten constants are close to the values provided by Diapharma Co. under nearly identical conditions. The proton inventory for $\mathrm{V}_{\max }$ for the bovine FXacatalyzed hydrolysis of S-2288 is shown in Figure 3.

Full progress curves were obtained with S-2765 $=1.0 \times 10^{-3} \mathrm{M}\left(4 \mathrm{~K}_{\mathrm{m}}\right)$ at $445 \mathrm{~nm}$ and the integrated Michaelis-Menten equation;(38) was fitted to the 1000 absorbance- time pairs for two runs to obtain the $\mathrm{k}_{\text {cat }}$ values used for the proton inventory curve in Figure 4. Values for $\mathrm{k}_{\mathrm{cat}} / \mathrm{K}_{\mathrm{m}}$ were obtained from these calculations with large errors, but gave a similar proton inventory to the one obtained from pseudo-first-order rate studies, conducted at $405 \mathrm{~nm}$ and $2.0 \times 10^{-5}$ M S-2765, shown in Figure 4.

\section{Model Selection for the Evaluation of Proton Inventory Data}

As detailed previously, $(30 ; 31)$ we developed a protocol based on the Gross-Butler equation, $(18 ; 19 ; 25 ; 41 ; 42)$ given below, which relates the dependence of a particular rate parameter to the atom fraction of deuterium, $\mathrm{n}$, in the solvent mixtures;

$$
\underset{\mathrm{i}}{\mathrm{TS}} \underset{\mathrm{V}=\mathrm{V}_{\mathrm{o}} \Pi\left(1-\mathrm{n}+\mathrm{n} \phi^{\mathrm{T}}{ }_{\mathrm{i}}\right) / \Pi\left(1-\mathrm{n}+\mathrm{n} \phi^{\mathrm{R}}{ }_{\mathrm{j}}\right)}{\mathrm{j}}
$$

where $V_{n}$ and $V_{o}$ are velocity (or rate constant) in a binary solvent and in water, respectively, $\mathrm{n}=$ atom fraction of deuterium, RS $=$ reactant state, $\phi^{\mathrm{R}}=\mathrm{RS}$ fractionation factor and $\phi^{\mathrm{T}}=\mathrm{TS}$ fractionation factor. The TS product is over TS fractionation factors and the RS product is over RS fractionation factors. The fractionation factors can be perceived as inverse equilibrium isotope effects, $\mathrm{K}_{\mathrm{D}} / \mathrm{K}_{\mathrm{H}}$, for exchange between a bulk water site and a particular structural site of RS or TS. The most common simplifications of this equation involve the assumption of a unit fractionation factor of RSs for catalytic residues with $\mathrm{NH}$ and $\mathrm{OH}$ functional groups and the assumption that one or two active-site units contribute in most hydrolytic enzymes. Based on our extensive experience with these systems, we fitted a variety of modifications of eq 1 to the data (See Supplemental Material) and accepted the model that gave the smallest reduced $\chi^{2}$ value and TS fractionation factors that are most consistent with both the $\mathrm{k}_{\mathrm{cat}} / \mathrm{K}_{\mathrm{m}}$ and $\mathrm{k}_{\mathrm{cat}}$ proton inventories. We calculated a single exponential term for a generalized solvent rearrangement (regardless its origin),(19;29) symbolized by $\phi_{\mathrm{S}}{ }^{\mathrm{n}}$, as best justified by past evidence. $(31 ; 43)$

\section{Discussion}

There is an increasing appreciation of the critical role of water structure in enzyme-catalyzed reactions. (44;45) In this light, KSIE and proton inventory studies on the hydrolysis of natural substrates catalyzed by FXa, seemed a worthwhile effort. Our study of the thrombin-catalyzed hydrolysis of two large natural protein substrates has shown a substantial role of solvent reorganization at the rate-limiting TS of these reactions.(30) Since the catalytic activity of FXa is more medium dependent than that of related enzymes studied to date, the activation of prothrombin is a unique target for studying the role of water structure in catalysis. Prothrombin activation at the aqueous-lipid interface is pivotal in the regulation of blood coagulation. Once the components of the prothrombin complex are surface bound, chemical transformations can occur at optimal speed. The process is associated with solvent restructuring and, thus, the physiological reaction catalyzed by FXa seems likely to show a strong contribution from solvent rearrangement. However, the challenge in kinetic measurements at the lipid-aqueous interface is not to be underestimated.(36,37,40,46) To assure consistency, buffered water and heavy water solutions of the reaction mixtures were made by dilution of common stock 
solutions in identical manner. The extrusion of vesicles was performed with great care to achieve uniform size.(46)

\section{Human Factor $\mathrm{Xa}$-Catalyzed Activation of Prothrombin}

FXa's critical physiological role is the activation of prothrombin to thrombin. The following general reaction scheme has been suggested, which explains the observation of the occurrence of active meizothrombin in the presence of membranes and FVa.(7;36;37)

At prothrombin concentrations well below $\mathrm{K}_{\mathrm{m}}$, the KSIEs are slightly inverse even in the absence of FVa and LUV. Wu et al. reported that the rate of the consecutive steps are comparable in the presence of $\mathrm{FVa}, \sim 5 \times 10^{-5} \mathrm{MLUV}$, and prothrombin concentrations below $\mathrm{K}_{\mathrm{m}}$.(37) However, the substrate dependence of the rate of FXa-catalyzed prothrombin activation varies at LUV concentrations 2 to $5 \times 10^{-5} \mathrm{M}$. The Michaelis-Menten parameters for prothrombin activation depend on the composition of the medium, which makes comparisons difficult. The $\mathrm{K}_{\mathrm{m}}$ value was reported to be 200 times greater in the absence of FVa and LUV than in their presence.(37) Our data displayed in Table 1A fully support these findings, as the second-order rate constants decline precipitously in the absence of FVa and in the absence of LUV. Although the reaction path changes with the medium, on the basis of the KSIE values $<1.0$, the chemical steps are not rate determining when the enzyme is not saturated with substrate and/or does not operate at optimal activity. The intervention of meizothrombin can only be demonstrated at high prothrombin concentrations, otherwise it is channeled to thrombin without release from the membrane-enzyme complex. $(9 ; 14 ; 47)$ The observed KSIEs in Table 1B reflect this observation in an interesting manner. KSIEs turn increasingly inverse, $0.30 \pm 0.05$ and $0.19 \pm 0.04$, indicating the predominance of a physical phenomenon as prothrombin concentrations increase. This is consistent with the proposal that meizothrombin accumulates with enhanced prothrombin concentrations and the overall rate is limited by either binding or a conformational change in order to poise the $\mathrm{Arg}^{322}-\mathrm{Ile}^{323}$ bond for cleavage. A conformational change was deemed necessary for the exposure and optimal projection of proteolytic sites in prothrombin.(16;47) Amino acids near the carboxyl segment of FVa heavy chain and FXa exosites bind prothrombin to exert the necessary structural reassembly for catalysis. $(10 ; 12)$ This transformation seems to be associated with an increase in the fractionation factors to $3.3-5.0$, due to the reorganization of myriads of solvating water molecules. In contrast, the observation of a KSIE of 2.0 at $2 \times 10^{-3} \mathrm{M} \mathrm{LUV}$ is consistent with a different rate-determining step, most likely, the formation of meizothrombin followed by rapid conversion to thrombin. Under less than optimal conditions, the chemical reactions leading to the formation of meizothrombin slow down.

\section{Human Factor Xa -Catalyzed Hydrolysis of Tripeptide Anilides}

Clearly, the contribution of TS proton bridges at the catalytic site of FXa cannot be assessed from studies of FXa-activation of prothrombin. Peptide-4-nitroanilide mimics of natural FXa substrates are ideal for this purpose. The chosen chromogenic tripeptides have the preferred Arg at the carboxyl side of the scissile bond and each carries preferred $\mathrm{P}_{2}$ and $\mathrm{P}_{3}$ residues. The KSIEs and proton inventories for the FXa-catalyzed hydrolysis of these substrates bespeak of very different type of proton bridges, forming at the TS in the rate-determining step of peptide hydrolysis, than the proton bridge originating from solvent restructuring. Both S-2288 and S-2765 present concave proton inventories when they saturate the enzyme, indicative of multiproton participation at the TS: 1) For $\mathrm{k}_{\text {cat }}$ for $\mathrm{S}-2288$, the fractionation factors obtained from the best statistical fit are (models and results of fits are provided in the Supplemental Material) $\phi_{1}=\phi_{2}=0.674 \pm 0.001$ indicating two equal proton bridges forming at the TS, KSIE $=1.48$ each. 2) For $\mathrm{k}_{\text {cat }}$ for S-2765, a very good substrate of FXa, $\phi_{1}=\phi_{2}=0.57 \pm 0.07$, indicating two equal proton bridges forming at the TS and $\phi_{S}=0.78 \pm 0.16$ for solvent restructuring. The curvature observable on Figure 4 arises from both, two proton bridges formed at the TS each 
associated with a KSIE of 1.69 and a normal SIE originating from the reorganization of countless solvent molecules Two proton bridges may also occur at the rate-determining TS for S-2765 below enzyme saturation with substrate $\left(\mathrm{k}_{\mathrm{cat}} / \mathrm{K}_{\mathrm{m}}\right)$, as measured with pseudo-first-order kinetics, but their strength cannot be established with certainty. Thus, unambiguous statistical distinction between the two-proton model with $\phi_{1}=\phi_{2}=0.73 \pm 0.01$ and one with a strong contribution of solvent rearrangement, $\phi_{S}=0.52 \pm 0.07$, while $\phi_{1}$ or $\phi_{1}=\phi_{2}=1.0 \pm 0.2$, is not possible in the latter case. Very good substrates of thrombin have also shown differences in fractionation factors depending on enzyme saturation with substrate. The TS fractionation factor is often unity under $\mathrm{k}_{\mathrm{cat}} / \mathrm{K}_{\mathrm{m}}$ conditions, which is consistent with a rate-determining physical step (binding or conformation al change) associated with solvent reorganization rather than rate-determining chemical steps. In any case, the rate-determining step is likely to be different when FXa is not saturated with S-2765 from when it is, because the fractionation factors are quite different.

The assignment of the TS fractionation factors to the participation of proton bridges solely in the breakdown of the tetrahedral intermediate occurring in acylation or in the formation of the tetrahedral intermediate in the hydrolysis of the acyl enzyme is uncertain. Their weighted average may be the most realistic account of the rate-determining TS: one or the other may dominate of course. The contribution of solvent rearrangement at the TS of the rate-determining step when FXa is saturated with S-2765 most likely indicates partial rate-determining leaving group departure accompanied by solvent reorganization. This has also been seen with the thrombin-catalyzed hydrolysis of two highly specific substrate mimics.(31)

The extent and nature of $\mathrm{P}$ and $\mathrm{P}^{\prime}$ sites in effectors of thrombin have a key role in mobilizing proton bridges at the rate-determining TS in acylation of the enzyme. Simple dipeptide amides invoke the participation of a single proton, while longer and more specific substrates recruit two or multi-proton participation in the formation of proton bridges at the TS. This is in accord with the efficiency of peptide bond cleavage indicated by the magnitude of $\mathrm{k}_{\mathrm{cat}} / \mathrm{K}_{\mathrm{m}} \cdot(17 ; 23)$ Schowen's hypothesis $(18 ; 20 ; 24-27)$ that subsites on peptide substrates exert a compression to elicit contraction of the distance between proton donors and acceptors in acid-base catalytic pairs at the enzymes' active site is validated by the thrombin and FXa-catalyzed reactions as by many previous protease-catalyzed reactions. H NMR signals of short strong hydrogen bonds (SSHBs) forming at the active site in serine hydrolases(48) including pancreatic proteases (49-53) and other enzymes, (54-58) when modified by mechanism-based inhibitors, have also been broadly studied and discussed. Proton transfer in these general-acid-base-catalyzed steps may be mediated by an SSHB at the TS.(21) Our present results with FXa-catalyzed hydrolysis of tripeptide pNA complement and support these perceptions.

The chief conclusion of these KSIE and proton inventory studies is that the rate-determining process in the FXa-catalyzed activation of prothrombin at the aqueous-lipid interface is dominated by physical events, most likely a conformational change accompanied by rearrangement of water structure while poising the scissile bond for nucleophilic attack by Ser. In contrast, when the chemical steps are revealed, as in the FXa-catalyzed hydrolysis of highly effective tripeptide 4-nitroanilides, multi-proton bridges are observed at the rate-determining TS: these are well-established properties of the active site of evolutionarily well-developed serine hydrolases.

\section{Supplementary Material}

Refer to Web version on PubMed Central for supplementary material. 


\section{Abbreviations}

APC, activated protein C

FXa, Factor Xa

FVa, Factor Va

KSIE, kinetic solvent isotope effect

LUV, large unilammellar vesicles

OD, optical density

$\mathrm{PC}$, protein $\mathrm{C}$

pNA, paranitroaniline

PCh, phosphatidylcholine

PS, phosphatidylserine

RS, reactant state

S-2765, N- $\alpha$-Z-DArg-Gly-Arg-pNA-2HCl

S-2288, H-D-Ile-L-Pro-L-Arg-pNA.HCl

S-2238, H-D-Phe-Pip-Arg-pNA

SSHB, short strong hydrogen bond

TLC, thin layer chromatography

$\mathrm{TS}$, transition state

\section{Reference List}

1. Furie B, Furie BC. The Molecular Basis of Blood Coagulation. Cell 1988;53:505-518. [PubMed: 3286010]

2. Davie EW, Fujikawa K, Kisiel W. The Coagulation Cascade: Initiation, Maintenance, and Regulation. Biochemistry 1991;29:10363-10370. [PubMed: 1931959]

3. Mann KG, Lorand L. Introduction: Blood Coagulation. Meth.Enzymology 1993;222:1-10.

4. Patthy L. Modular Design of Proteases of Coagulation, Fibrinolysis, and Complement Activation: Implications for Protein Engineering and Structure-Function Studies. Meth.Enzymology 1993;222:10-22.

5. Brandstetter H, Kuhne A, Bode W, Huber R, der Saal W, Wirthensohn K, Engh RA. X-ray Structure of Active Site-inhibited Clotting Factor Xa. IMPLICATIONS FOR DRUG DESIGN AND SUBSTRATE RECOGNITION. J.Biol.Chem 1996;271:29988-29992. [PubMed: 8939944]

6. Padmanabhan K, Padmanabhan KP, Tulinsky A, Park CH, Bode W, Huber R, Blankenship DT, Cardin AD, Kisiel W. Structure of human des(1-45) factor Xa at 2.2 A resolution. J.Mol.Biol 1993;232:947966. [PubMed: 8355279]

7. Rosing J, Tans G, Govers-Riemslag JW, Zwaal RF, Hemker HC. The role of phospholipids and factor $\mathrm{Va}$ in the prothrombinase complex. J.Biol.Chem 1980;255:274-283. [PubMed: 7350159]

8. Husten EJ, Esmon CT, Johnson AE. The active site of blood coagulation factor Xa. Its distance from the phospholipid surface and its conformational sensitivity to components of the prothrombinase complex. J.Biol.Chem 1987;262:12953-12961. [PubMed: 3477541]

9. Carlisle TL, Bock PE, Jackson CM. Kinetic intermediates in prothrombin activation. Bovine prethrombin 1 conversion to thrombin by factor X. J.Biol.Chem 1990;265:22044-22055. [PubMed: 2254347]

10. Nesheim ME, Foster WB, Hewick R, Mann KG. Characterization of Factor V activation intermediates. J.Biol.Chem 1984;259:3187-3196. [PubMed: 6421819]

11. Bukys MA, Blum MA, Kim PY, Brufatto N, Nesheim ME, Kalafatis M. Incorporation of factor Va into prothrombinase is required for coordinated cleavage of prothrombin by factor Xa. J. Biol.Chem 2005;29:27393-27401. [PubMed: 15897196]

12. Beck DO, Bukys MA, Singh LS, Szabo KA, Kalafatis M. The Contribution of Amino Acid Region Asp695-Tyr698 of Factor V to Procofactor Activation and Factor Va Function. J.Biol.Chem 2004;279:3084-3095. [PubMed: 14559913]

13. Rezaie AR, Esmon CT. Contribution of Rsidue 192 in Factor Xa to Enzyme Specificity and Function. J.Biol.Chem 1995;270:16176-16181. [PubMed: 7608183] 
14. Boskovic DS, Bajzar LS, Nesheim ME. Channeling During Prothrombin Activation. J.Biol.Chem 2001;276:28686-28693. [PubMed: 11384970]

15. Kalafatis M, Beck DO, Mann KG. Structural Requirements for Expression of Factor Va Activity. J.Biol.Chem 2003;278:33550-33561. [PubMed: 12788947]

16. Vijayalakshmi J, Padmanabhan KP, Mann KG, Tulinsky A. The isomorphous structures of prethrombin2, hirugen-, and PPACK-thrombin: Changes accompanying activation and exosite binding to thrombin. Protein Sci 1994;3:2254-2271. [PubMed: 7756983]

17. Hedstrom L. Serine protease mechanism and specificity. Chem.Rev 2002;102:4501-4524. [PubMed: 12475199]

18. Alvarez, FJ.; Schowen, RL. Mechanistic Deductions from Solvent Isotope Effects.. In: Buncel, E.; Lee, CC., editors. Isotopes in Organic Chemistry. Elsevier; Amsterdam: 1987.

19. Kresge, AJ.; More, O.; Powell, MF. Solvent Isotopes Effects, Fractionation Factors and Mechanisms of Proton Transfer Reactions.. In: Buncel, E.; Lee, CC., editors. Isotopes in Organic Chemistry. Elsevier; Amsterdam: 1987.

20. Schowen, RL. Structural and Energetic Aspects of Protolytic Catalysis by Enzymes: Charge - Relay Catalysis in the Function of Serine Proteases.. In: Liebman, JF.; Greenberg, A., editors. Mechanistic Principles of Enzyme Activity. VCH Publishers; New York: 1988.

21. Schowen KB, Limbach HH, Denisov GS, Schowen RL. Hydrogen bonds and proton transfer in general-catalytic transition state stabilization in enzyme catalysis. Biochem.Biophys.Acta 2000;1458:43-62. [PubMed: 10812024]

22. Quinn, DM.; Sutton, LD. Theoretical Basis and Mechanistic Utility of Solvent Isotope Effects.. In: Cook, PF., editor. Enzyme Mechanism from Isotope Effects. CRC Press; Boston, MA: 1991.

23. Fersht, A. Structure and Mechanism in Protein Science. W. H. Freeman \& Co.; New York: 1999.

24. Elrod JP, Hogg JL, Quinn DM, Schowen RL. Protonic Reorganization and Substrate Structure in Catalysis by Serine Proteases. J.Am.Chem.Soc 1980;102:5365-5376.

25. Venkatasubban KS, Schowen RL. The Proton Inventory Technique. CRC Crit.Rev.Biochem 1985;17:1-44. [PubMed: 6094099]

26. Stein RL, Elrod JP, Schowen RL. Correlate Variations in Enzyme - Derived and Substrate - Derived Structures of Catalytic Transition States. Implications for the Catalytic Strategy of Acyl - Transfer Enzymes. J.Am.Chem.Soc 1983;105:2446-2452.

27. Stein RL, Strimpler AM, Hori H, Powers JC. Catalysis by Human Leukocyte Elastase: Proton Inventory as a Mechanistic Probe. Biochemistry 1987;26:1305-1314. [PubMed: 3032250]

28. Scholten JD, Hogg JL, Raushel FM. Methyl Chymotrypsin Catalyzed Hydrolysis of Specific Substrate Esters Indicate Multiple Proton Catalysis Is Possible with a Modified Charge Relay Triad. J.Am.Chem.Soc 1988;110:8246-8247.

29. Chiang Y, Kresge AJ, Chang TK, Powell MF, Wells JA. Solvent Isotope Effects on a Hydrolysis Reaction Catalyzed by Subtilisin and Its N155G Mutant - Failure of the Proton Inventory method to Report Hydrogen-Bonding Interactions in the Oxyanion Hole. J.Chem.Soc.,Chem.Commun 1995:1587-1588.

30. Zhang D, Kovach IM. Full and Partial Deuterium Solvent Isotope Effect Studies of -Thrombincatalyzed Reactions of Natural Substrates. J.Am.Chem.Soc 2005;127:3760-3766. [PubMed: 15771510]

31. Enyedy EJ, Kovach IM. Proton Inventory Studies of Thrombin-Catalyzed Reactions of Substrates with Selected P and P' Sites. J.Am.Chem.Soc 2004;126:6017-6024. [PubMed: 15137766]

32. Schellenberger V, Turck CW, Rutter WJ. Role of the S' Subsites in Serine Protease Catalysis. ActiveSite Mapping of Rat Chymotrypsin, Rat Trypsin, $\alpha$-Lytic Protease, and Cercarial Protease from Schistosoma mansoni. Biochemistry 1994;33:4251-4257. [PubMed: 8155642]

33. Schellenberger V, Turck CW, Hedstrom L, Rutter WJ. Mapping the S' Subsites of Serine Proteases Using Acyl Transfer to Mixtures of Peptide Nucleophiles. Biochemistry 1993;32:4349-4353. [PubMed: 8476865]

34. Le Bonniec BF, Myles T, Johnson T, Knight CG, Tapparelli C, Stone SR. Characterization of the $\mathrm{P}_{2}$ ' and $\mathrm{P}_{3}$ ' Specificities of Thrombin Using Fluorescence-Quenched Substrates and Mapping of the Subsites by Mutagenesis. Biochemistry 1996;35:7114-7122. [PubMed: 8679538] 
35. Dai Y, Hedstrom L, Abeles RH. Inactivation of Cystein Proteases by (Acyloxy) Methyl Ketones Using S'-P' Interactions. Biochemistry 2000;39:6498-6502. [PubMed: 10828965]

36. Banerjee M, Majumder R, Weinreb G, Wang J, Lentz BR. Role of procoagulant lipids in human prothrombin activation. 2. Soluble phosphatidylserine upregulates and directs factor $X(a)$ to appropriate peptide bonds in prothrombin. Biochemistry 2002;41:950-957. [PubMed: 11790118]

37. Wu JR, Zhou C, Majumder R, Powers DD, Weinreb G, Lentz BR. Role of Procoagulant Lipids in Human Prothrombin Activation. 1. Prothrombin Activation by Factor X(a) in the Absence of Factor V(a) and in the Absence and Presence of Membranes. Biochemistry 2002;41:935-949. [PubMed: 11790117]

38. Goudar CT, Sonnad JR, Duggleby RG. Parameter estimation using a direct solution of the integrated Michaelis-Menten equation. Biochim. Biophys. Acta 1999;1429:377-383. [PubMed: 9989222] referemces therein

39. Leatherbarrow, RJ. GraFit User's Guide. Ertihacus Sofware Ltd.; Staines, U.K.: 1992. 1992

40. Chen L, Yang L, Rezaie AR. Proexosite-1 on Prothrombin Is a Factor Va-dependent Recognition Site for the Prothrombinase Complex. J.Biol.Chem 2003;278:27564-27569. [PubMed: 12750382]

41. Gold V. Protolytic processes in $\mathrm{H}_{2} \mathrm{O}-\mathrm{D}_{2} \mathrm{O}$ mixtures. Adv.Phys.Org.Chem 1969;7:259-331.

42. Kresge AJ. Solvent isotope effects in $\mathrm{H}_{2} \mathrm{O}-\mathrm{D}_{2} \mathrm{O}$ Mixtures. Pure Appl.Chem 1964;8:243-258.

43. Stein RL. Transition-State Properties for the Association of $\alpha-1$-Protease Inhibitor with Porcine Pancreatic Elastase. J.Am.Chem.Soc 1985;107:6039-6042.

44. Park C, Raines RT. Quantitative Aanalysis of the Effect of Salt Concentration on Enzyme Catalysis. J.Am.Chem.Soc 2001;123:11472-11479. [PubMed: 11707126]

45. Ru MT, Hirokane SY, Lo AS, Dordick JS, Reimer JA, Clark DS. On the Salt-Induced Activation of Lyophilized Enzymes in Organic Solvents: Effect of Salt Kosmotropicity on Enzyme Activity. J.Am.Chem.Soc 2000;122:1565-1571.

46. Mayer LD, Hope MJ, Cullis PR. Vesicles of variable sizes produced by a rapid extruison procedure. Biochem. Biophys. Acta 1986;858:161-168. [PubMed: 3707960]

47. Chattopadhyay A, James HL, Fair DS. Molecular Recognition Sites on Factor Xa Which Participate in the Prothrombinase Complex. J.Biol.Chem 1992;267:12323-12329. [PubMed: 1601896]

48. Mildvan AS, Massiah MA, Harris TK, Marks GT, Harrison DHT, Viragh C, Reddy PM, Kovach IM. Short Strong Hydrogen Bonds on Enzymes: NMR and Mechanistic Studies. J.Mol.Stucture 2002;215:163-175.

49. Frey PA, Whitt SA, Tobin JB. A Low-Barrier Hydrogen Bond in the Catalytic Triad of Serine Proteases. Science 1994;264:1927-1930. [PubMed: 7661899]

50. Tobin JB, Whitt SA, Cassidy CS, Frey PA. Low-Barrier Hydrogen Bonding in Molecular Complexes Analogous to Histidine and Aspartate in the Catalytic Triad of Serine Proteases. Biochemistry 1995;34:6919-6924. [PubMed: 7766600]

51. Cassidy CS, Lin J, Frey PA. A New Concept for the Mechanism of Action of Chymotrypsin: The Role of the Low-Barrier Hydrogen Bond. Biochemistry 1997;36:4576-4584. [PubMed: 9109667]

52. Lin J, Westler WM, Cleland WW, Markley JL, Frey PA. Fractionation factors and activation energies for exchange of the low barrier hydrogen bonding proton in peptidyl trifluoromethyl ketone complexes of chymotrypsin. Proc.Natl.Acad.Sci 1998;95:14664-14668. [PubMed: 9843946]

53. Lin J, Cassidy CS, Frey PA. Correlations of the Basicity of His 57 with Transition State Analogue Binding, Substrate Reactivity, and the Strength of the Low-Barrier Hydrogen Bond in Chymotrypsin. Biochemistry 1998;37:11940-11948. [PubMed: 9718318]

54. Halkides CJ, Wu YQ, Murray CJ. A Low-Barrier Hydrogen Bond in Subtilisin: ${ }^{1} \mathrm{H}$ and ${ }^{15} \mathrm{~N}$ NMR Studies with Peptidyl Trifluoromethyl Ketones. Biochemistry 1996;35:15941-15948. [PubMed: 8961961]

55. Ash EL, Sudmeier JL, De Fabo EC, Bachovchin WW. A Low-barrier Hydrogen Bond in the Catalytic Triad for Serine Proteases? Theory Versus Experiment. Science 1997;278:1128-1132. [PubMed: 9353195]

56. Kahayaoglu A, Haghjoo K, Guo F, Jordan F, Kettner C, Felfoldi F, Polgar L. Low Barrier Hydrogen Bond is Absent in the Catalytic Triads in the Ground State but is Present in a Transition-state Complex in the Prolyl Oligopeptidase Family of Serine Proteases. J.Biol.Chem 1997;272:25547-25554. [PubMed: 9325271] 
57. Bao D, Huskey PW, Kettner CA, Joradn F. Hydrogen Bonding to Active-Site Histidine in Peptidyl Botonic Acid Inhibitor Complexes of Chymotrypsin and Subtilisin: Proton Magnetic Resonance Assignments and H/D Fractionation. J.Am.Chem.Soc 1999;121:4684-4689.

58. Massiah MA, Viragh C, Reddy PM, Kovach IM, Johnson J, Rosenberry TL, Mildvan AS. Short, Strong Hydrogen Bonds at the Active Site of Human Acetylcholinesterase: Proton NMR Studies. Biochemistry 2001;40:5682-5690. [PubMed: 11341833] 


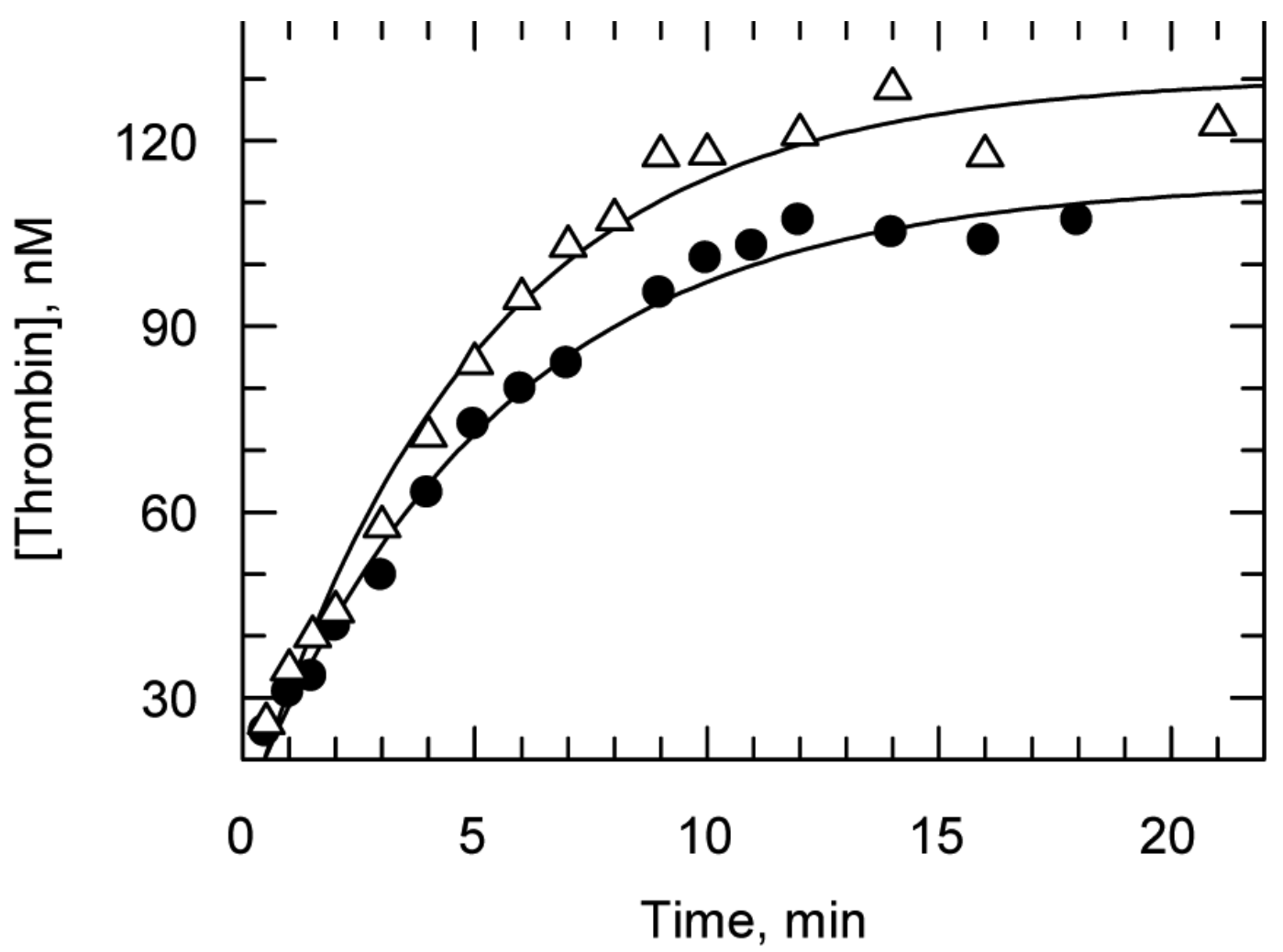

Figure 1.

Time dependence of human FXa-catalyzed human prothrombin activation in the presence of four-fold excess of FVa, at $\mathrm{pH} 7.50,0.020 \mathrm{M}$ Tris buffer, $5.0 \times 10^{-5} \mathrm{M} \mathrm{LUV}, 5 \times 10^{-3} \mathrm{M}$ $\mathrm{CaCl}_{2}$ and $25.0 \pm 0.1^{\circ} \mathrm{C}$. The filled circles represent $\mathrm{H}_{2} \mathrm{O}$ buffer and triangles in $\mathrm{D}_{2} \mathrm{O}$ buffer. 


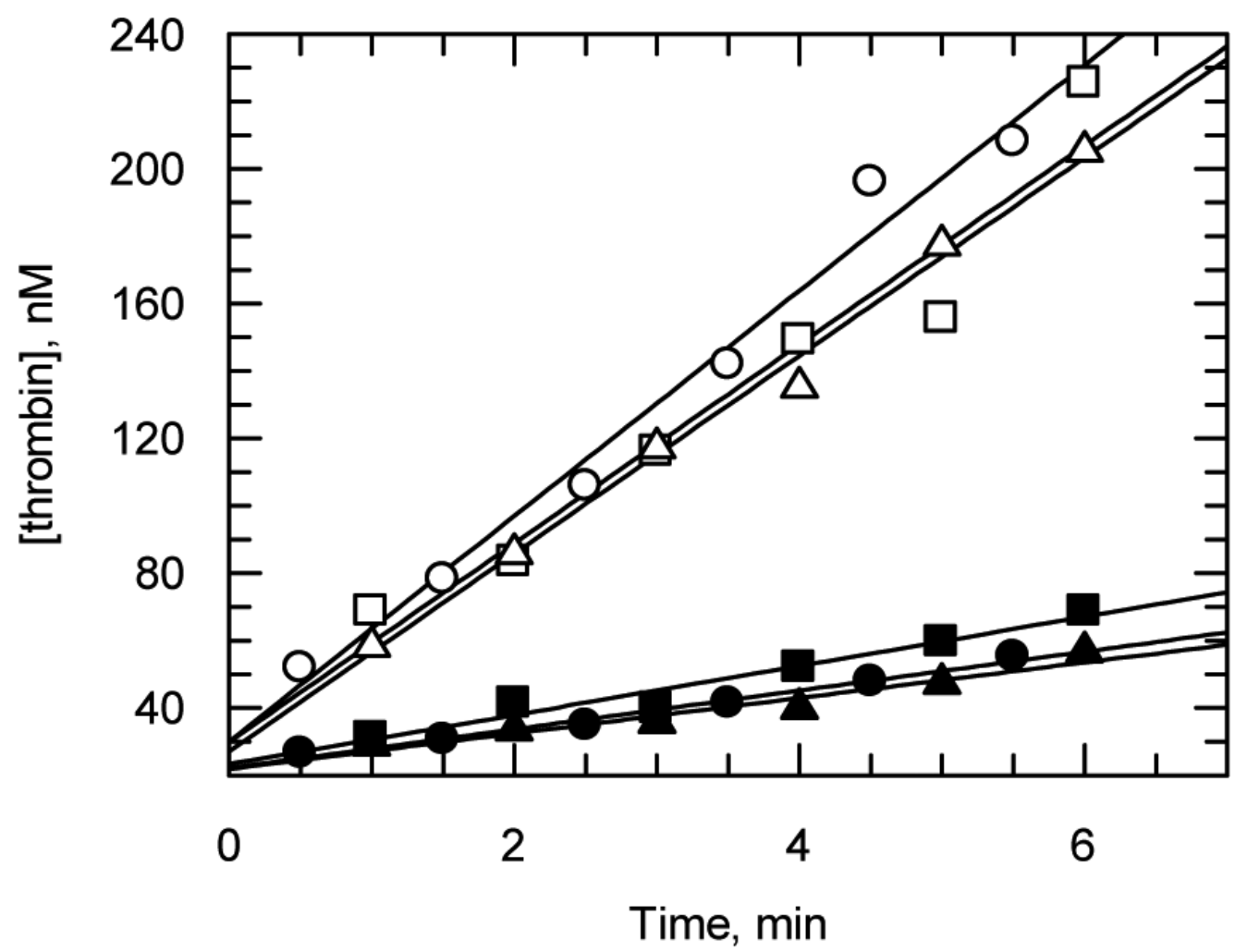

Figure 2.

Initial rates of human FXa-catalyzed human prothrombin activation in the presence of fourfold excess of FVa, at $\mathrm{pH} 7.50,0.020 \mathrm{M}$ Tris buffer, $5.0 \times 10^{-5} \mathrm{M} \mathrm{LUV}, 5 \times 10^{-3} \mathrm{M} \mathrm{CaCl}^{2}$ and $25.0 \pm 0.1^{\circ} \mathrm{C}$. Filled symbols represent $\mathrm{H}_{2} \mathrm{O}$, and open symbols $\mathrm{D}_{2} \mathrm{O}$. 


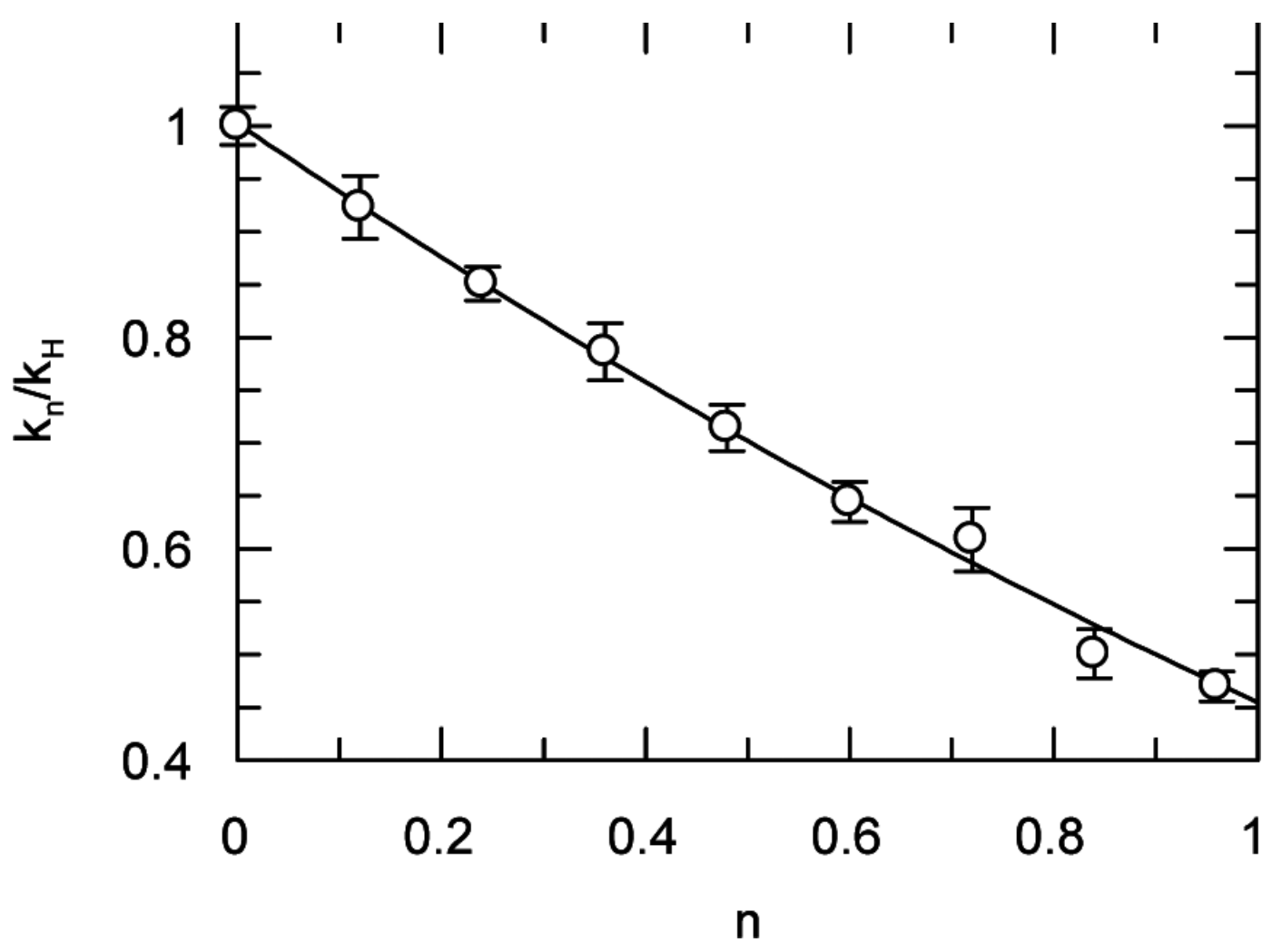

Figure 3.

Ratios of initial rates measured in mixed isotopic solvents over the initial rates measured in water plotted against the atom fraction of deuterium, $n$, for bovine FXa-catalyzed S-2288 hydrolysis at $\mathrm{pH} 8.40$ and equivalent $\mathrm{pL}, 0.020 \mathrm{M}$ Tris buffer, $0.30 \mathrm{M} \mathrm{NaCl}, 5 \times 10^{-3} \mathrm{M}$ $\mathrm{CaCl}_{2}, 0.1 \%$ PEG4000, 2\% DMSO at $25.0 \pm 0.1{ }^{\circ} \mathrm{C}$. The equation of the line is $\mathrm{k}_{\mathrm{n}} / \mathrm{k}_{\mathrm{H}}=1.0$ $(1-n+n / 1.5)^{2}$ 


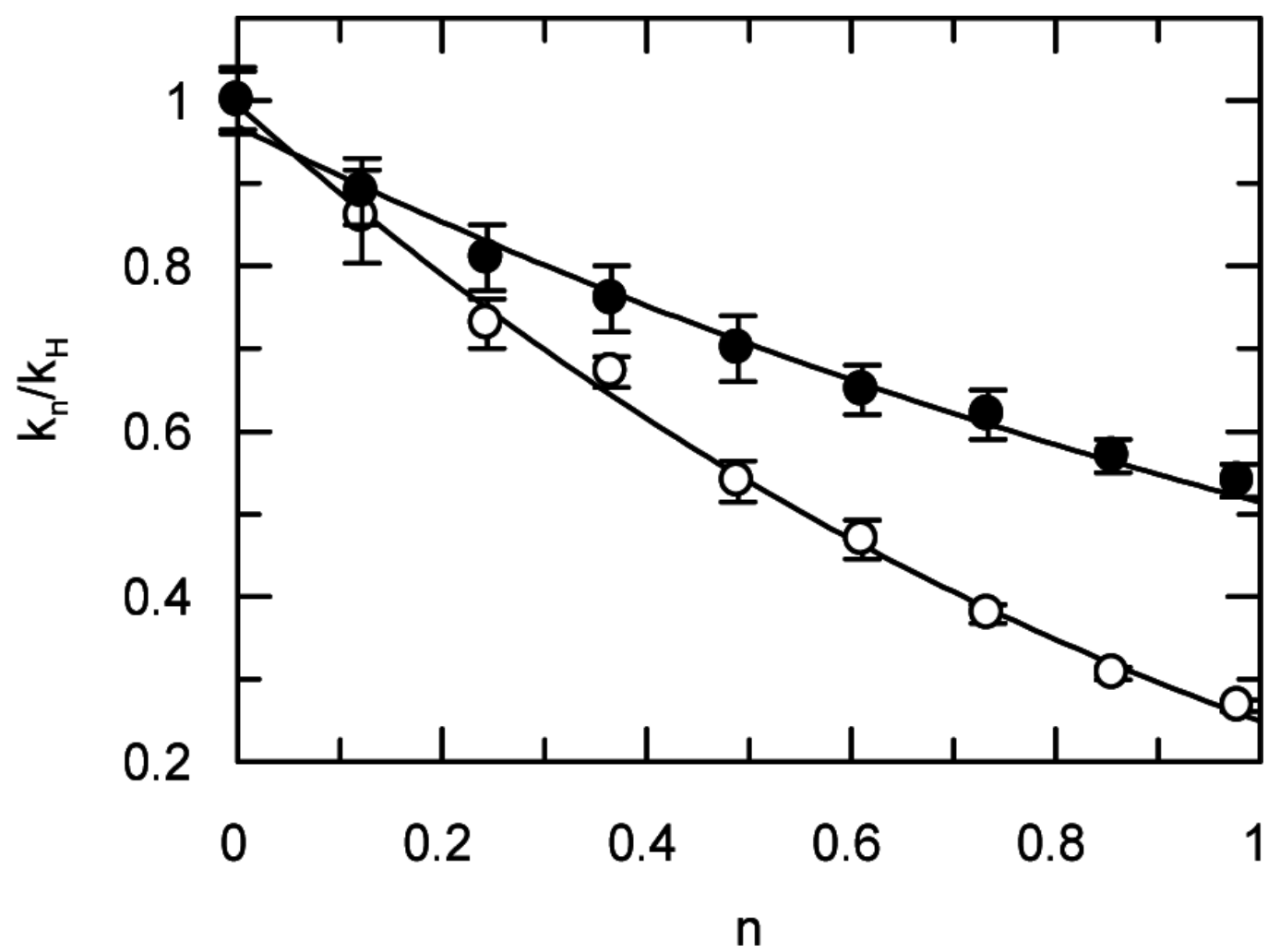

Figure 4.

Ratios of rate constants measured in mixed isotopic waters over the rate constants measured in water plotted against the atom fraction of deuterium, $n$, for the FXa-catalyzed hydrolysis of S-2765 at pH 8.40 and equivalent pL, 0.020 M Tris buffer, $0.30 \mathrm{M} \mathrm{NaCl}, 5 \times 10^{-3} \mathrm{M} \mathrm{CaCl}_{2}$, and $0.1 \%$ PEG-4000 and $25.0 \pm 0.1{ }^{\circ} \mathrm{C}$. Open circles represent $\mathrm{k}_{\mathrm{cat}}$ data and the equation of the line is $\mathrm{k}_{\mathrm{n}} / \mathrm{k}_{\mathrm{H}}=1.0(1-\mathrm{n}+\mathrm{n} / 1.75)^{2} 0.78_{\mathrm{n}}$. Filled circles are for $\mathrm{k}_{\mathrm{cat}} / \mathrm{K}_{\mathrm{m}}$ and the equation of the line is $\mathrm{k}_{\mathrm{n}} / \mathrm{k}_{\mathrm{H}}=1.0(1-\mathrm{n}+\mathrm{n} / 1.37)^{2}$. 

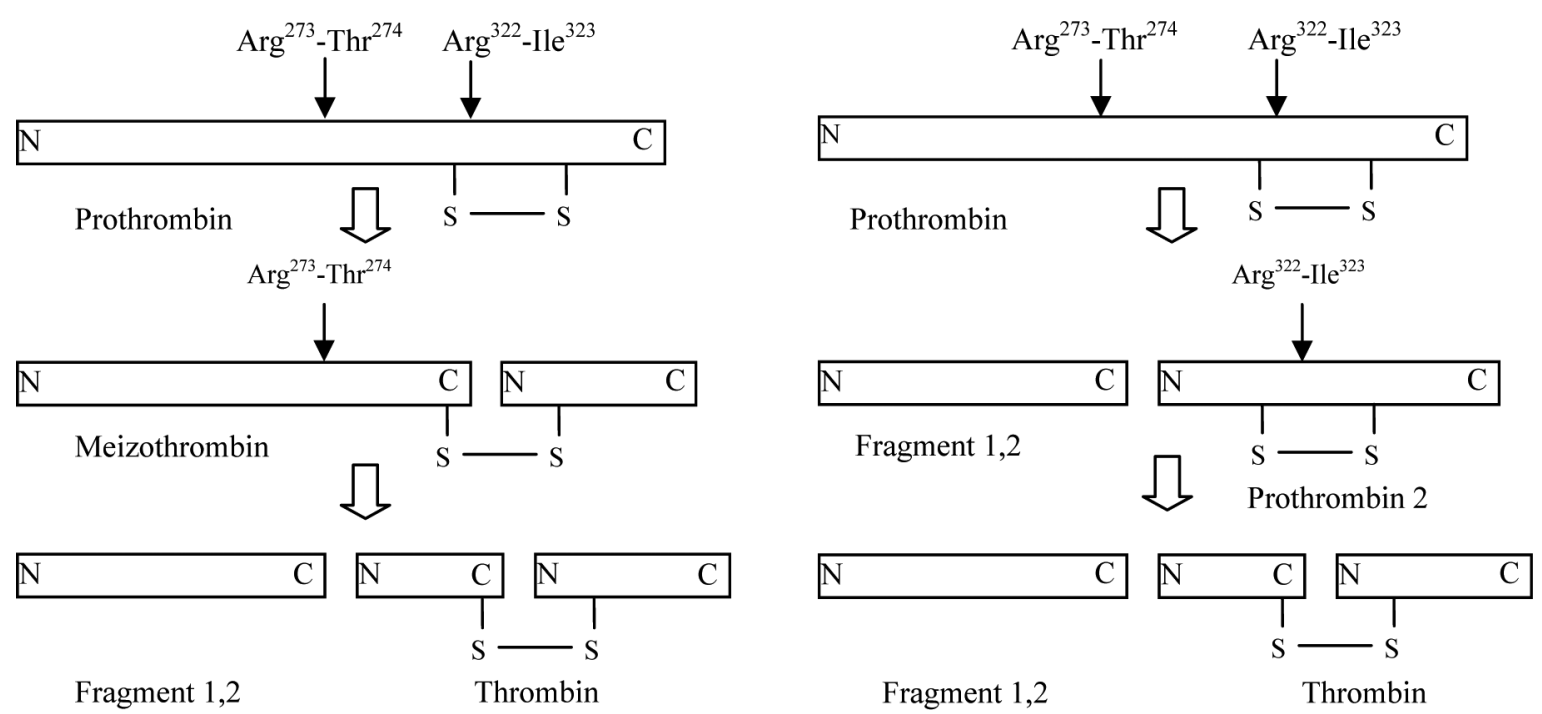

Scheme 1.

Thrombin production from human prothrombin: the balance of the pathways on the left and right is a function of conditions. $(7 ; 36 ; 37)$ 
Table 1

Solvent isotope effects for human FXa-catalyzed human prothrombin activation at pH 7.50 in $0.020 \mathrm{M}$ Tris buffer and $25.0 \pm 0.1^{\circ} \mathrm{C}$.

\begin{tabular}{|c|c|c|c|c|}
\hline \multirow[b]{2}{*}{$\begin{array}{l}10^{6}[\mathrm{LUV}] \mathrm{M} \\
10^{9}[\mathrm{FXa}] \mathrm{M} \\
10^{9}[\mathrm{FV}] \mathrm{M} \\
10^{6}[\text { Prothrombin }] \mathrm{M} \\
\mathrm{k}_{\mathrm{cat}} / \mathrm{K}_{\mathrm{m}}(\mathrm{H}), \mathrm{M}^{-1} \mathrm{~s}^{-1} \\
\mathrm{k}_{\mathrm{cat}} / \mathrm{K}_{\mathrm{m}}(\mathrm{D}), \mathrm{M}^{-1} \mathrm{~s}^{-1} \\
\mathrm{KSIE}\end{array}$} & \multicolumn{4}{|c|}{ A. Pseudo-first order kinetics } \\
\hline & $\begin{array}{c}50 \\
0.33 \\
1.3 \\
0.20 \\
(7.6 \pm 1.2) \times 10^{6} \\
(9.0 \pm 1.7) \times 10^{6} \\
0.84 \pm 0.22\end{array}$ & $\begin{array}{c}50 \\
10 \\
- \\
0.30 \\
(3.9 \pm 0.1) \times 10^{4} \\
(4.8 \pm 0.3) \times 10^{4} \\
0.82 \pm 0.07\end{array}$ & $\begin{array}{c}- \\
93 \\
- \\
4.1 \\
164 \pm 9 \\
188 \pm 9 \\
0.87 \pm 0.06\end{array}$ & $\begin{array}{c}- \\
493 \\
- \\
25 \\
62 \pm 2 \\
66 \pm 1 \\
0.93 \pm 0.04\end{array}$ \\
\hline & \multicolumn{4}{|c|}{ B. Initial rate method } \\
\hline $\begin{array}{l}10^{6}[\mathrm{LUV}] \mathrm{M} \\
10^{9}[\mathrm{FXa}] \mathrm{M} \\
10^{9}[\mathrm{FV}] \mathrm{M} \\
10^{6}[\text { Prothrombin }] \mathrm{M} \\
\mathrm{k}_{\text {cat }}, \mathrm{s}^{-1}(\mathrm{H}) \\
\mathrm{k}_{\text {cat }}, \mathrm{s}^{-1}(\mathrm{D}) \\
\text { KSIE }\end{array}$ & $\begin{array}{c}50 \\
0.33 \\
1.3 \\
6.8 \\
0.31 \pm 0.05 \\
1.6 \pm 0.2 \\
0.19 \pm 0.04\end{array}$ & $\begin{array}{c}50 \\
0.33 \\
1.3 \\
4.0 \\
0.67 \pm 0.01 \\
2.2 \pm 0.2 \\
0.30 \pm 0.05\end{array}$ & $\begin{array}{c}50 \\
1.0 \\
1.0 \\
4.0 \\
0.28 \pm 0.05 \\
0.18 \pm 0.01 \\
1.56 \pm 0.31\end{array}$ & $\begin{array}{c}50 \\
15 \\
- \\
9.9 \\
(1.74 \pm 0.20) \times 10^{-3} \\
(2.53 \pm 0.14) \times 10^{-3} \\
0.69 \pm 0.09\end{array}$ \\
\hline
\end{tabular}

